\title{
A győri jármüipari körzetről szóló kutatási program
}

\author{
Research programme on the \\ Vehicle Industrial District in Györ
}

\author{
RECHNITZER JÁNOS
}

RECHNITZER János: tanszékvezető egyetemi tanár, Széchenyi István Egyetem, RegionálisTudományi és Közpolitikai Tanszék, Győr; rechnj@sze.hu

KULCSSZAVAK: Győr, autóipar, járműipari körzet

ABSZTRAKT: Magyarország piacgazdasági átmenete óta Budapest mellett Győr ipari térsége emelkedett ki, a város Kelet-Közép-Európa egyik jármüipari központjává vált. Az Audi gyárában kétmillió motor és százezer autó készül évente. A térség számos beszállítója a jármüiparban tevékenykedik, más innovatív vállalatok mellett. A Széchenyi István Egyetem a járműipar és a közlekedési rendszerek kutatása köré szerveződött, amelyben a regionális tudományi kutatások is megjelentek. A magyar regionális tudomány nem foglalkozott az elmúlt években az ipari körzetek kérdésével. A TÁMOP4.2.2.A-11/1/KONV-2012-0010 A Győri Jármüipari Körzet, mint a térségi fejlesztés új iránya és eszköze címü kutatási programot ennek a hiánynak a betöltésére indítottuk. 2012 őszén indultak el az elemzések, amelyek befejezése 2014 őszére várható. Bevezetőm célja, hogy rövid áttekintést adjak a kutatási program tartalmáról, annak célkitűzéseiről és a Tér és Társadalom e számában közreadott tudományos eredmények beágyazottságáról.

János RECHNITZER: professor, head of department, Department of Regional Studies and Public Policy, Széchenyi István University, Győr; rechnj@sze.hu

KEYWORDS: Győr, automotive industry, industrial district

ABSTRACT: Hungarian regional studies have not addressed the topic of industrial districts in recent years. Since Hungary's transition to market economy, the only important industrial region to emerge in addition to Budapest was Györ and its surroundings. Györ is a traditional industrial town. It is located close to the center of the triangle formed by Vienna, Bratislava and Budapest.

Györ has been one of the headquarters of automotive industry in Central and Eastern Europe. On Audi's Hungarian site, two million engines and a hundred thousand cars are produced every year. Many suppliers are connected to the automotive industry in this area. However, other innovative companies can be found in the town and the surrounding area as well.

Széchenyi István University is also located here. The academic profile of this institution is focused on automotive industry and transportation systems. Our research team has conducted several research projects on the location factors and supplier relations of this sector in Hungary and in CEE countries. Based on former research projects, in autumn 2012 we successfully launched the new research programme: Györ Regional Vehicle Industrial District as a New

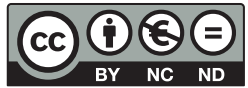


Direction and Instrument of Regional Development (TÁMOP-4.2.2.A-11/1/KONV-2012-0010). We expect to complete this project by autumn 2014.

The theoretical objective of this project is to provide a conceptual model of growth centers as a new instrument of regional development. We examine the theoretical basis of location and spatial economy as well as the process of district formation. We discuss the role of the state and local governments in establishing districts. The project analyzes European urban development, highlights the specific characteristics of Central and Eastern European urban regions, and describes changes in Hungary's urban network structure. This issue summarizes the findings of the theoretical component of our research programme.

The empirical component traces the development of Györ and the surrounding region. It describes the development of the local economy in the 20th century and analyzes the transformation of economic structures since Hungary's transition to market economy until today. We study the regional impact of the agglomeration of urban functions and public utilities. The social structure of the town and its surrounding region is also carefully examined because this information is essential to a reliable assessment of future development.

To summarize, we describe a successful center of Hungarian modernization and assess possible development trajectories. At a theoretical level, the research programme is also expected to contribute to the research methodology of studying urban development.

\section{Bevezetés}

A társadalom területi szerkezetének kutatása az elmúlt 30 esztendőben megerösödött hazánkban. A regionális tudomány néven összegzett új tudományág intézményi keretei kialakultak, létrejöttek oktatási, kutatási bázisai, publikációs fórumai, széles nemzetközi kapcsolatai és beágyazottságai, valamint humán erőforrásai, amelyek a doktori iskoláktól az akadémiai doktori minősítésig terjednek.

Ennek az új tudományágnak a megjelenése Győrben akadémiai kutatócsoport, később intézet alapításával kezdődött (1986), majd a Széchenyi István Egyetem jogelődjénél a kilencvenes évek elején folytatódott. A felsőoktatási intézményben első fázisban önálló szakirányként, aztán mesterszakként, 2004-től pedig doktori képzés keretében jelent meg a regionális tudomány, majd a második fázisban a 2010-es évek elejétől a tudományterületen önálló kutatási program indult.

A hely szelleme hatott ezekre a programokra, hiszen az egyetem tudományos profilja, amely a jármüipar és a közlekedési rendszerek kutatása köré szerveződött, természetesen fogadta be, sőt megkövetelte e szektorok és tevékenységek térgazdasági elemzését. A 2012-ben zárult kutatás (TÁMOP4.2.1./B-09/KONV-2010-0003 Mobilitás és környezet: Jármüipari, energetikai és környezeti kutatások a Közép- és Nyugat-dunántúli régióban) során a jármüipar telepítési tényezőit tekintettük át Kelet-Közép-Európában, keresve a magyarországi és a térségi pozíciókat, s elemezve a beszállítói hálózatok sajátosságait, szervezeti és működési tényezőit (Rechnitzer, Smahó 2012a; 2012b). Ezek az eredmények vetették fel a kutatócsoportban azt a tudományos kérdést, hogy miként szerveződik egy járműiparra épülő térség, annak milyen gazdasági, társa- 
dalmi, intézményi, hálózatszervező sajátosságai írhatók le, s miként lehet fejlo"dését különféle eszközökkel befolyásolni, alakítani.

A tudományos kérdéseket a TÁMOP-4.2.2.A-11/1/KONV-2012-0010 A Györi Jármüipari Körzet, mint a térségi fejlesztés új iránya és eszköze című kutatási programban dolgozzuk ki, 2012 őszén indultak el az elemzések, amelyek befejezése 2014 őszére várható. Terveink szerint a kutatás eredményeit öt magyar és két angol nyelvü kötetben adjuk közre, amelyek 2014 végére jelennek meg.

Bevezetőm célja, hogy rövid áttekintést adjak a kutatási program tartalmáról, annak célkitűzéseiről és a Tér és Társadalom e számában közreadott tudományos eredmények beágyazottságáról.

\section{Egy hazai nagyváros fejlődési trendje}

Győr és térsége ${ }^{1}$ Magyarország legdinamikusabban fejlődő övezete. Győr megyei jogú város, egyben Győr-Moson-Sopron megye székhelye. A város mind Budapesttől, mind Bécstől 120 km-re fekszik, a szlovák fővárostól pedig 80 km-re. Győrt és térségét a szomszédos országok fövárosaival (Bécs, Pozsony) és a hazai fövárossal gyorsforgalmi közúti, vasúti és vízi közlekedési kapcsolatok kötik össze. A város közelében két nemzetközi repülőtér (Bécs, Pozsony) és kikötő (Győr-Gönyü, Révkomárom) is található.

A város közlekedési kapcsolatai kiválóak. A település két (IV., VII.) európai közlekedési folyosó mentén helyezkedik el. Az Észak-Dunántúl gazdasági életét meghatározó közlekedési foútvonalak a városból indulnak ki, illetve érintik azt. Győr rendelkezik regionális repülőtérrel (Győr-Pér) és kikötővel (Győr-Gönyü).

A rendszerváltás gazdasági traumái viszonylag kedvező helyzetben érték a várost; előnyös földrajzi pozíciójának és sokrétủ gazdasági szerkezetének köszönhetően gyors fejlődésnek indulhatott a kilencvenes években. Győr a külföldi tőke kedvelt célállomásává vált, ami új iparágak megjelenésével tovább diverzifikálta a város gazdaságszerkezetét. Világcégek telepedtek meg a városban az Audihoz beszállítóként kapcsolódva, de jelen vannak a fejlett technológiai szintet képviselő külföldi és hazai kis- és középvállalkozások is.

Győr a Dunántúl egyik középiskolai központja. Az 1977-ben megalakult Közlekedési és Távközlési Műszaki Főiskola képzési kínálata az elmúlt évtizedekben folyamatosan bővült, 2002-ben pedig létrejött a Széchenyi István Egyetem. Az egyetemen a meghatározó műszaki tudományok mellett gazdaságtudományi, jogi, zene- és egészségtudományi oktatás is zajlik, jelenleg 22 alap- és 18 mesterszakon, három doktori iskolában. A győri felsőoktatási intézmények hallgatóinak létszáma megközelíti a tizenhétezer főt.

Győr és a Nyugat-Dunántúl régió másik négy nagyvárosának összevetésekor egyértelmű Győr vezető helyzete, ellátottsági mutatói szinte minden szférában magasabbak, mint a régió más megyei jogú vagy felsőoktatással is 
rendelkező városai esetében. Egyedül a vezető oktatók arányában és az MTA köztestületi tagok (tudományos minősítéssel rendelkezők) esetében van enyhe lemaradása Soprontól, de az összes megújítást hordozó tényezőben kiugró Győr előnye, és a többi hazai regionális központhoz, fejlesztési pólushoz hasonlóak az értékei.

Egyértelműen leszögezhető, hogy Győr felzárkózott a tradicionális magyarországi regionális központokhoz; erős, folyamatosan megújuló gazdasági potenciálja megindította a felsőoktatás és a kutatás-fejlesztés új rendszereinek kiépülését. Mindezt ösztönzi, hogy a gyakorlati innovációs folyamatot szervező és alakító, egyben az új technológiákat képviselő gazdasági és fejlesztő szervezetek nagy számban megtalálhatók legyenek a városban.

Győr fejlesztésének célja, hogy a Bécs-Pozsony-Budapest kelet-közép-európai fejlődési övezet alközpontjaként olyan regionális centrummá váljon, amelyben a tudást szolgáló intézményrendszer egyre teljesebb kiépítésével folyamatosan megújulnak az ipari, technikai adottságok. Cél, hogy a város intézményrendszere képes legyen segíteni Észak-Dunántúl térségének integrációját az új európai fejlődési övezetbe, s ezt a beépülést a városi környezetet fenntartó, egyben adottságait növelő fejlesztés teremtse meg, aminek révén vonzó életkörülmények biztosíthatók a központban és a térségben élők számára.

$\mathrm{Az}$ innovációt a fejlődés fókuszába helyező várospolitika iránya, hogy megteremtődjenek az ipar és a szolgáltatások folyamatos megújításának feltételei, de annak miliője is. Ehhez kedvező feltételeket nyújt a városban koncentrálódó, e szektorokhoz erősen kötődő tudásbázis, az egyetemi képzés és a kutatás-fejlesztési potenciál. A fejlesztéspolitika eredményeivel egy olyan növekedési centrum alakulhat ki az Észak-Dunántúl térségében, amely alkotórésze lehet az európai regionális központok hálózatának, s képes a régió egészében további dinamikus fejlődést indukálni.

Győr tradicionális ipari központ, amely a kilencvenes években képes volt modernizálni a gazdaság szerkezetét. A korábban is meghatározó járműipari szerkezet megújult azáltal, hogy a német Audi AG tulajdonában lévő Audi Hungaria Motor Kft. 1994-ben motorgyárat létesített a városban. A gyár napjainkban kétmillió gépjárműmotort állít elő, hamarosan évi 100 ezer gépjárműt fog összeszerelni, s ennek is köszönhetően egyre több korszerű ipari és szolgáltató egység telepszik meg a városban és térségében. Győr folyamatosan építette ki regionális szolgáltató funkcióit, ami felölelte az egyetemi szintű oktatást, az egészségügyet, a kereskedelmet, a magas szintü üzleti és technológiai szolgáltatásokat, valamint a kulturális kínálatot és a sporttevékenységeket.

A város jövőbeli fejlődésében új súlypontok alakultak ki. Az első, hogy az egyre látványosabban szerveződő Bécs-Pozsony-Győr fejlődési övezet részének tekinthető, ahol új típusú hálózati együttműködések jöhetnek létre. Csak Győr képes korszerü logisztikai bázisával, intézményi adottságaival, koncentrálódó tudásszintjével, egyre látványosabban formálódó felsőoktatásával és kutatásfejlesztési bázisaival Észak-Dunántúlt, annak gazdaságát és településhálózatát ebbe az új európai fejlődési övezetbe integrálni. 
A másik fejlődési súlypont, hogy az egyre szélesebb kapcsolatokkal rendelkező lokális és regionális gazdaság újabb és újabb igényeket fogalmaz meg a szellemi erőforrások iránt, ezért azok működési feltételeinek javítása - a szakképzés, a felsőfokú képzés, valamint a kutatás-fejlesztés-innováció területén - elkerülhetetlen.

A harmadik súlypont, hogy megnőtt az igény a városi környezet átalakítására, annak felzárkóztatására az európai regionális központok szintjére, valamint új elemek megjelentetésével (kulturális szolgáltatások fejlesztése) az életminőség javítására.

A város új innovációs pályához érkezett, amelynek a fejlesztési irányai az alábbiakban határozhatók meg:

- a tudásbázisok és a tudás intézményrendszereinek kiépítése;

- a technikai bázist szolgáló új szolgáltatások fejlesztése;

- a regionális együttműködések skáláinak szélesítése;

- a városi miliő és környezet új elemeinek megteremtése.

A fejlesztés a fenti négy alrendszerhez kapcsolódó vezérprojektekben valósul meg, amelyek természetesen egymásra is jelentős hatással vannak, ennek következében kölcsönös szinergiát biztosítanak a város jövőjéhez.

\section{A kutatási irányok és a tervezett eredmények}

Az európai fejlesztési trendek (Területi agenda 2020), a hazai fejlesztési irányok (Új Széchenyi-terv, Széll Kálmán-terv 1 és 2, Magyar növekedési terv, Országos fejlesztési és területfejlesztési koncepció), továbbá a város és régiója által generált folyamatok együttesen lehetőséget nyújthatnak arra, hogy alapkutatás igényével feltárjuk hazánkban egy gazdasági, ipari - kiemelten járműipari - orientációjú növekedési központ működését, annak fejlesztését és térbeli hatásait alakító tényezők rendszerét. A kutatás éppen egy sikeres, funkcióiban gazdag, termelési bázisában előremutató, térségi kapcsolataiban szerteágazó járműipari körzet elemzésén keresztül kínálhat új közelítéseket a hazai és a nemzetközi fejlesztéspolitikának, annak elméletének és gyakorlatának.

A kutatás két szinten valósul meg, így a célok is ezekben a dimenziókban érvényesülnek.

Elméleti szinten cél a növekedési központ, majd az ipari körzet mint új térségformáló és -fejlesztő rendszer elméleti modelljének alapos, szakszerű leírása. Ennek az elemző bemutatásnak tartalmaznia kell azokat a sajátosságokat, amelyek a kelet-közép-európai térségben érvényesülnek, kiemelve a gazdasági szerkezetet, a városhálózat adottságait, valamint a terület- és településfejlesztés eszköz- és intézményrendszerét.

Az elméleti kutatásoknak választ kell adniuk a növekedési pólusok fejlődési folyamataira, azok belső tartalmainak változására, arra, hogy azok kialakulá- 
sát, majd növekedését milyen tényezők motiválják, miként határozhatók meg a fejlődési szintek. Vizsgálniuk kell, hogy az átmenet a növekedési pólus és az ipari körzet között milyen tényezőkre vezethető vissza, s ebben milyen nemzetközi sajátosságok ismerhetők fel.

Kimutatható volt a korábbi kutatásokban, hogy az állam szerepet játszhat a pólusok, majd a körzetek szerveződésében; e beavatkozások kutatása szintén az elméleti blokk része. Felmerül annak kérdése, hogy milyen szabályozási modellek alkalmazhatók, hol jelenik meg a lokális szintek szerepe, azokban melyek a governance (kormányzás) jellegü beavatkozások keretei, intézményi bázisai.

Az európai városhálózatban át kell tekinteni a kelet-közép-európai nagytérség városi szerkezetét, keresve a fejlődési azonosságokat és különbözőségeket. Egyben elemezni szükséges a kelet-közép-európai városhálózatban az ipari bázisra épülő nagyközpontok helyzetét, összehasonlítva azok adottságait, értékelve versenyképességüket, meghatározva azokat az ipari potenciálokat, amelyek a jelenben és a jövőben (a következő 10-15 évben) meghatározhatják fejlődésüket.

Az elméleti kutatások között vizsgáljuk a gazdasági fejlődés és a növekedési pólusok, ipari körzetek kapcsolatát, azok egymásrautaltságát, kölcsönös determinizmusait. Modelleket állítunk fel a városfejlődést mozgató tényezők rendszerére, azok függőségi viszonyaira, belső kapcsolataik rendszerére, továbbá ábrázoljuk az egymás közötti függőségi viszonyokat. A modellekkel fejlesztési szcenáriók kidolgozására is törekszünk, hogy egzakt módon levezethetők legyenek a kutatás más szegmenseiben meghatározott beavatkozások hatásai, eredményességük vagy éppen negatív következményeik.

A kutatás tehát egy magyar nagyváros példáján modellezi az ipari - jármüipari - orientáltságú fejlesztés lehetséges irányait és akciótereit. Ezzel a fejlesztéspolitika rádiuszát tágíthatja, annak új megoldásokat, technikákat kínálva. Itt kell megemlíteni várható tudományos eredményként a területi együttműködés - a városi, térségi kormányzás - új intézményi modelljeinek bemutatását, amelyek vonatkozhatnak a közszolgáltatások megszervezésétől kezdve a térségi erőforrások újszerű hasznosításán át egészen a tervezési és fejlesztési rendszer intézményi keretéig. A kutatás több térségi együttmúködési modellt dolgoz ki, amelyek segíthetik a fejlesztés - ezen belül a terület- és a városfejlesztés - hatékonyságának növelését, s ezzel az elaprózott források kedvezőbb felhasználását.

Az elemzések bázisul szolgálhatnak a 2014-2020-as európai uniós tervezési időszak tudományos megalapozásához, éppen ennek az új területi szerveződési formának a feltárásával, annak működésének és fejlesztési orientációjának leírásával. Alkalmasak lehetnek a kutatási eredmények arra, hogy a térség egészéről, annak belső (intraregionális), határon belüli és kívüli (interregionális) kapcsolatairól olyan megállapításokat, ajánlásokat tegyenek, amelyek hozzájárulnak a tervezés megalapozásához, annak részben módszertani, részben tartalmi szélesítéséhez.

A folyóiratban közölt tanulmányok ennek az elméleti fejezetnek néhány eredményét adják közre. Egy kutatás tervezésekor a célok széles skáláját vázol- 
juk fel, aztán az elemzésekkel igazolhatjuk vagy elvethetjük ezeket, illetve korrigálhatjuk irányaikat. Nos, a továbbiakban közölt tanulmányok részben mélyítették a feltételezéseinket, részben a várakozásainkat mérsékelték.

A kutatások második szakasza az empirikus elemzéseket tartalmazza, amelyek már kimondottan a városra és térségére vonatkoznak. Az eredmények alátámaszthatják az elméleti modellekben foglalt megállapításokat, adhatnak igazolást arra, hogy létrejött-e az ipari körzet, vagy hogy az miként követi a kialakult - nyugat- és kelet-európai - szerkezeteket, s milyen beavatkozásokkal, fejlesztésekkel járulhatnak hozzá az itteni szereplők a sikerességhez.

A hazai regionális tudományi alapkutatások még nem foglalkoztak komplex közelítésben a növekedési pólusokkal és az azokra épülő ipari nagycentrumok szerkezetének és térségi hatásainak elemzésével. Így a program során kidolgozzuk e területi szerkezetek elemzési módszereit, ezek tesztelésével más nagyvárosok esetében is alkalmazhatók lesznek a vizsgálati eljárások.

Ebben a blokkban kell megemlíteni azokat a kutatásokat, amelyek Győr és térségét tárják fel. A modern, ipari Győrre vonatkozó történeti kutatások, így döntően a 20. századi fejlődési folyamatok elemzései inkább mozaikszerüek voltak, mint rendszerezettek. Rendelkezünk ugyan ismeretekkel a város és térsége történetét alakító tényezőkről, azonban ezek alaposabb, igényesebb feltárása nem történt meg. Csak közelítően ismerjük a belső erőforrásokat mozgató tényezők történeti gyökereit, így a tudástermelés és -átadás rendszereit, az ipari, gazdasági kultúra terjedésének technikáit és azok közvetítőit, vagy a megújítást ösztönző magatartások jellegét és mozgatórugóit. Ezek nélkül a „győri modell” nem érthető meg, és nem dolgozható ki alakításának iránya és menete sem.

Nagy jelentőséget tulajdonítunk annak, hogy megvizsgáljuk a város és térsége társadalmi szerkezetét. Az elmúlt 30 évben nem végeztek mélyreható társadalomszerkezeti elemzéseket ebben a régióban, így a kutatás nemcsak egy hiányt pótol, hanem egy átalakuló, a gazdasági és társadalmi folyamatokra gyorsan és hatékonyan reagáló nagyváros és régiója szerkezeti keresztmetszetét készíti el, a megfelelő mélységü felmérésekkel.

Az empirikus vizsgálatok második célja magának a győri járműipari körzetnek a feltárása, tudományos leírása, erőforrásainak értékelése, a város és térsége kapcsolatrendszerének meghatározása, az együttműködések szervezeti, intézményi és finanszírozási kereteinek kijelölése, s végül egy új típusú - térségi szintű - tervezési és fejlesztési rendszer sarokpontjainak kidolgozása.

Ebben a kutatási metszetben ki kell emelni azokat a vizsgálatokat, amelyek az ipari körzet lehatárolására vonatkoznak, a gazdasági funkcióktól kezdve a szociális és közszolgáltatási szerepkörökön át a képzés és az oktatás intézményeinek térségalakításáig. Új eredményeket várunk mind módszertanilag, mind pedig a konkrét térség esetében, hiszen az elemzések arra is szolgálnak, hogy bővítsék a regionális tudomány eszköztárát.

Az empirikus kutatások harmadik célja a térségi szintű kutatási és oktatási együttmüködések tesztelése, majd ezek alapján azok tartalmi, intézményi kere- 
teinek megteremtése. Az elemzések lehetővé teszik, hogy a térségben a kutatási, felsőoktatási, önkormányzati, gazdasági, szakmai és tudományos szervezetek témában érintett szereplői határon belül és kívül folyamatosan kommunikáljanak, új együttműködéseket generáljanak. Ezzel kívánjuk erősíteni a formálódó társadalomtudományi kutatóműhely hálózatát, ösztönözni a gazdaság és a társadalom területi kutatásának helyi intézményeit, s azok integrálását a hazai és nemzetközi tudományos kezdeményezésekbe.

\section{Jegyzet}

1 Térség alatt a város körül kialakult 60-100 km-es vonzáskörzetet értjük, ennek súlyponti városai: Komárom, Tatabánya, Veszprém, Pápa, Kapuvár, Mosonmagyaróvár, s az országhatáron túl Dunaszerdahely, Révkomárom. A térséget pontosabban az elemzés első fázisában határoljuk le.

\section{Irodalom}

Rechnitzer J., Smahó M. (szerk.) (2012a): Jármüipar és a regionális versenyképesség. Nyugat- és KözépDunántúl a kelet-közép-európai térségben. Széchenyi University Press, Győr

Rechnitzer J., Smahó M. (szerk.) (2012b): A jármüipar beszállitói hálózata Kelet-Közép-Európában és Magyarországon. Széchenyi University Press, Győr 